\title{
Evaluation of the effect of different beverages on the mechanical properties of orthodontic arch wires
}

\section{Ahmad Mohammad Hafez*}

\section{ABSTRACT:}

Purpose: This study was conducted to evaluate the effect of different beverages on surface microhardness, modulus of elasticity and flexural strength of orthodontic archwires. Materials and Methods: Four orthodontic archwires (stainless steel, $\mathcal{N} i T_{i}$, copper $\mathcal{N i T i}$ and Teflon-coated $\mathcal{N i T i}$ ) were used. They were immersed in three different solutions (Artificial saliva, tea and Coca Cola) for four weeks. For mechanical properties assessment, the specimens were classified mainly into four groups (90 specimens each) according to the archwire type. Each group was further subdivided into 3 subgroups (30 specimens each) according to the used solution. Each subgroup had been divided into three divisions (10 specimens each) according to the test parameter (surface microhardness, modulus of elasticity, flexural strength). Surface microhardness was evaluated using Vickers hardness tester. While modulus of elasticity and flexural strength were measured by subjecting the archwires specimens to the three point bending test using a universal testing machine. Means and standard deviations were calculated for all tests. The data was analyzed and compared using two-way $\mathcal{A N O} \mathcal{N} \mathcal{A}$ analysis and Least Significant Difference (LSD) test $(p<0.05)$. Results: Artificial saliva significantly decreased the surface microhardness of St. St. and Teflon-coated $\mathcal{N} i T_{i}$ archwires and significantly decreased the modulus of elasticity of $\mathcal{N} i T_{i}$, CuNiTi, St. St. archwires. Tea and Coca Cola significantly decreased the surface microhardness of CuNiTi, St. St. and Teflon-coated $\mathcal{N} i T_{i}$ archwires and significantly decreased the modulus of elasticity of all archwire specimens. Two-way ANOV $\mathcal{A}$ A results revealed significant difference among the tested groups $(p<0.001)$. Conclusions: Tea and Coca Cola potentially would contribute to the change in the mechanical properties of orthodontic archwires leading to prolonged orthodontic treatment.

Keywords: Mechanical properties; Orthodontic archwires; Beverages; 3 point bending test.

\section{INTRODUCTION}

Ideally, archwires are designed to move teeth with light and continuous forces. These forces may minmize the potential for patient discomfort, tissue hyalinization and undermining bone resorption. 1 When such forces are applied, the archwire should behave elastically over a period of weeks to months. To accomplish this objective, four major orthodontic archwire alloys are available which are; nickeltitanium, beta-titanium, stainless steel and cobaltchromium-nickel archwires. ${ }^{2}$ Each archwire alloy system has unique properties and characteristics. When archwires are used to treat patients, their elastic property ratios indicate that each alloy excels at a particular juncture whether in the initial, intermediate or final stages of treatment. ${ }^{3}$

\footnotetext{
* Lecturer, Department of Orthodontics, Faculty of Dentistry, Mansoura University, Mansoura, Egypt
} 
Nonetheless, several properties and characteristics should be considered in the search for the ideal archwire. Among them are esthetics, bio- stability, friction, formability, weldability, resilience and spring back action. ${ }^{3}$ Orthodontic metallic materials are usually consisted of alloys including various base metals such as nickel, cobalt, chromium, iron, titanium and molybdenum. ${ }^{4}$ As orthodontic treatments may extend over several months, the aesthetic appearance of the appliance is rated by patients as a significant factor and to meet this demand, different types of aesthetic archwires have been developed such as Teflon, epoxy resin-coated archwires and fiber reinforced polymeric composites. ${ }^{5}$

The oral cavity is a complicated environment in which orthodontic appliances are vulnerable to chemical, thermal and mechanical risks. Acids produced by intraoral bacteria and from drinks can cause archwire corrosion and influence the physical and mechanical properties of orthodontic archwires. ${ }^{6-16}$

In the light of the aforementioned factors, mechanical and surface properties of the archwires might be of value. There is still no consensus regarding the effect of different drinks on archwires. So, this study was conducted for more clarification on their effect on the surface microhardness, modulus of elasticity and flexural strength of stainless steel, NiTi, copper NiTi and Teflon-coated NiTi arch wires. The null hypothesis was that the oral environment and daily use of these beverages have no effect on their mechanical properties.

\section{Materials and methods}

Specimens used in this study are shown in Table 1. Different four preformed archwires $(0.019 \times 0.025$ inches $)$ were chosen. For mechanical properties assessment, the 360 specimens (25 mm length, cut from the straight portion of the preformed archwires) were classified mainly into four groups (90 specimens each) according to the archwire type. Each group was further subdivided into 3 subgroups (30 specimens each) according to the used solution. Then each subgroup had been divided into three divisions (10 specimens each) according to the test parameter (surface microhardness, modulus of elasticity, flexural strength). Specimens of these archwires were immersed in the following solutions; artificial saliva (control ), tea and Coca Cola respectively for four weeks. The studied archwires were immersed in the testing solutions for 3 minutes once / day in a trial to mimic the oral condition.

Table 1: Types, composition and manufacturer of orthodontic archwires used in the study.

\begin{tabular}{|c|c|c|c|}
\hline Archwire & Composition (wt \%) & Manufacturer & Batch no. \\
\hline St. St. & $\begin{array}{c}71 \% \mathrm{Fe}, 8 \% \mathrm{Ni}, \\
18 \% \mathrm{Cr}, 0.2 \% \mathrm{C}\end{array}$ & $\begin{array}{c}\text { Ortho-Organizers, } \\
\text { Inc, Sanmarcos, } \\
\text { California;USA }\end{array}$ & 109893 \\
\hline NiTi & $\begin{array}{c}54.9 \% \mathrm{Ni}, 44.9 \% \mathrm{Ti}, \\
0.2 \% \mathrm{Cr}\end{array}$ & $\begin{array}{c}\text { Ortho-Organizers, } \\
\text { Inc, Sanmarcos, } \\
\text { California;USA }\end{array}$ & 122263 \\
\hline CuNiTi & $\begin{array}{c}49.1 \% \mathrm{Ni}, 45.7 \% \mathrm{Ti}, \\
0.2 \% \mathrm{Cr}, 5 \% \mathrm{Cu}\end{array}$ & $\begin{array}{c}\text { OrthoTechnology Inc, } \\
\text { Tampa, Florida;USA }\end{array}$ & 1311960 \\
\hline Teflon-coated \\
NiTi & $\begin{array}{c}52 \% \mathrm{Ni}, 45 \% \mathrm{Ti}, \\
\mathrm{Cr}, \text { in addition to the } \\
\text { coating layer of } \\
\text { polytetrafluoroethylene. }\end{array}$ & $\begin{array}{c}\text { OrthoPro, Orlando, } \\
\text { Florida;USA }\end{array}$ & 04013 \\
\hline
\end{tabular}




\section{Preparation of the artificial saliva:}

The artificial saliva was prepared in the faculty of Pharamcy, Mansoura university, Egypt. It consisted of $0.4 \mathrm{gm} 0 \mathrm{NaCl}, 1.210 \mathrm{gm} 0 \mathrm{KCl}$, $0.78 \mathrm{gm} \mathrm{NaH}_{2} \mathrm{PO}_{4} 2 \mathrm{H}_{2} \mathrm{O}, 0.005 \mathrm{~g} \mathrm{Na}_{2} \mathrm{~S}, 1 \mathrm{~g}$ urea $\mathrm{CO}\left(\mathrm{NH}_{2}\right)_{2}$ in $1000 \mathrm{ml}$ distilled water.6-8 Then, $0100 \mathrm{mg} / 10$ of bovine serum albumin was added to the artificial saliva.

\section{Determination of surface microhardness:}

The surface microhardness was measured for the prepared specimens of the different subgroups. It was evaluated at room temperature using a microhardness tester equipped with the Vickers indenter (Vickers Hardness Tester, Tukon 1102 Buehler, Germany). Specimens were fixed on the tester's holder and adjusted under the microscope.

Vickers diamond tip was used to make indentations on each specimen's surface. A standard force of $100 \mathrm{~g}$ was applied via the Vickers diamond pyramid for 10 seconds dwell time. Vickers hardness number was calculated according to the following equation; ${ }^{25}$

$\mathbf{V H N}=\mathbf{1 8 5 4 . 4} \times \mathbf{P} / \mathbf{d} 2$, where VHN is Vickers hardness number $\left(\mathrm{kg} / \mathrm{mm}^{2}\right), P$ is the applied load and $\mathrm{d}$ is the diagonal of the indentation.

\section{Determination of modulus of elasticity}

The prepared archwires specimens for each subgroup were subjected to a three point bending test using a Universal Testing Machine (Instron model 3345, England) at the room temperature, with a load cell of $5 \mathrm{~N}$. The setup included a specially constructed fixture comprising two poles placed $14 \mathrm{~mm}$ apart, which was chosen in accordance with the ANSI / ADA specification no. 32 on a stage attached to the lower jaw of the machine. The tested archwire specimens were secured on edgewise stainless steel twin brackets fixed on the poles utilizing 0.012 inch elastomeric ligatures. Though some authors ${ }^{26}$ had reported that metal ligatures produce less friction than the elastomeric ligatures, the force generated during the placement of the metal ligature is susceptible to be subjective and could differ according to the orthodontist. Compressive force was applied at a crosshead speed of $0.5 \mathrm{~mm} /$ min by means of a steel rod with a unibeveled chisel and placed midway between the two poles. Either specimen was loaded to a deflection of $3 \mathrm{~mm}$. Deflections in a graded order were used due to the possibility of plastic deformation or fracture of the tested specimens when submitted to large deflections. Load in newtons and deflection in millimeters were recorded for each specimen with a computer software program (BlueHill 3 software version 3.3).

Based on the load deflection curve and the dimensions of the specimens, the flexural stress as a function of flexural strain was determined for each specimen. The modulus of elasticity of the archwire specimens was determined from a stress-strain curve by calculating the ratio of stress to strain or the slope of the linear region of the curve. The modulus is calculated from the following equation; ${ }^{9-11} \mathbf{E}=\boldsymbol{\sigma} / \boldsymbol{\varepsilon}$, where $\mathbf{E}$ is modulus of elasticity, $\boldsymbol{\sigma}$ is the stress and $\varepsilon$ is the strain.

\section{Determination of flexural strength}

The prepared archwires specimens for each subgroup were subjected to a three point bending test using the Universal Testing Machine at the room temperature with a load cell of $5 \mathrm{~N}$. Compressive force was applied at a crosshead speed of $0.5 \mathrm{~mm} / \mathrm{min}$ by the steel rod. Each specimen was loaded to a deflection of $3 \mathrm{~mm}$. Load in newtons and deffection in millimeters were recorded for each specimen. Based on the load deflection curve and the dimensions of the specimens, the flexural stress as a function of flexural strain was determined for each specimen. The flexural strength 
is calculated from the following equation; ${ }^{10-13}$

$\boldsymbol{\sigma}=\mathbf{3 P I} / \mathbf{2} \mathbf{b d}^{\mathbf{2}}$, where $\boldsymbol{\sigma}$ is the stress, $\mathbf{P}$ is the load, $\mathbf{I}$ is the length, $\mathbf{b}$ is the width and $\mathbf{d}$ is the thickness of the archwire.

\section{Statistical analysis}

Means and standard deviations of the surface microhardness, modulus of elasticity and flexural strength were calculated for all groups. The data was analyzed and compared using two-way ANOVA. Least Significant Difference (LSD) test $(\alpha=0.05)$ was performed to determine the differences between archwire specimens. Statistical calculations were performed using the Statistical Package for the Social Sciences (SPSS) software program, version 20.

\section{Results}

\section{Surface microhardness}

Mean values and standard deviations $(\mathrm{kg} / \mathrm{mm} 2)$ of the different orthodontic archwires in different solutions are shown in Table 2. The highest mean value was found to be $572.33+6.08$ $\mathrm{kg} / \mathrm{mm} 2$ for St. St. archwire in the artificial saliva (control), while the lowest mean value was found to be $17.03+0.58 \mathrm{~kg} / \mathrm{mm}^{2}$ for Teflon-coated NiTi archwire in tea. Two-way ANOVA results revealed significant difference among the tested groups $(\mathrm{p}<0.001)$.

Table 2: Means and standard deviations $(\mathrm{kg} / \mathrm{mm} 2)$ of surface microhardness of all tested groups.

\begin{tabular}{|c|c|c|c|c|c|c|}
\hline & $\begin{array}{c}\text { NiTi } \\
(\text { Mean+SD) }\end{array}$ & $\begin{array}{c}\text { CuNiTi } \\
(\text { Mean+SD })\end{array}$ & $\begin{array}{c}\text { St. } \mathbf{S t} . \\
(\text { Mean+SD) }\end{array}$ & $\begin{array}{c}\text { Teflon-coated } \\
\text { NiTi } \\
(\text { Mean+SD) }\end{array}$ & P-value & LSD value \\
\hline $\begin{array}{c}\text { Artificial saliva } \\
\text { (control) }\end{array}$ & $400.70+4.52^{\mathrm{Aa}}$ & $381.27 \pm 4.15^{\mathrm{Ba}}$ & $572.33 \pm 6.08^{\mathrm{Ca}}$ & $27.33 \pm 2.66^{\mathrm{Da}}$ & $<0.0001$ & 11.5 \\
\hline Tea & $394.68+6.92^{\mathrm{Aa}}$ & $374.80+3.63^{\mathrm{Bb}}$ & $565.67 \pm 5.81^{\mathrm{Cb}}$ & $17.03+0.58^{\mathrm{Dc}}$ & $<0.0001$ & 8.1 \\
\hline Coca Cola & $389.40 \pm 6.51^{\mathrm{Aa}}$ & $345.10+6.43^{\mathrm{Bd}}$ & $533.93+3.86^{\mathrm{Cc}}$ & $19.31 \pm 0.30^{\mathrm{Dbc}}$ & $<0.0001$ & 9.2 \\
\hline P-value & 0.3777 & $<0.0001$ & 0.0003 & $<0.0001$ & & \\
\hline LSD value & 12.26 & 7.37 & 12.26 & 2.52 & & \\
\hline
\end{tabular}

Means with the same superscript capital letters in the same raw and the same superscript small letters in the same column are not significantly different

The LSD test results (Table 2) revealed that there was a significant difference between the various archwires surface microhardness mean values in all solutions. Regarding the NiTi archwire group, there was no significant difference in surface microhardness means of all media. For CuNiTi archwire group, there was a significant difference between surface microhardness means of control and tea, control and Coca Cola, tea and Coca Cola and between solution subgroups $(\mathrm{p}<0.001)$.

Regarding St. St. archwire group, there was a significant difference between surface microhardness means of control and tea and control and Coca Cola solution subgroups. In relation to Teflon-coated NiTi archwire group, there was a significant difference between surface microhardness means of control and tea and control and Coca Cola solution subgroups $(\mathrm{p}<0.001)$.

\section{Modulus of elasticity}

Modulus of elasticity mean values and standard deviations ( $\mathrm{MPa}$ ) of tested orthodontic archwires in different solutions are shown in Table 3. The highest mean value was found for St. St. archwire in the control group $(14.81+0.21 \mathrm{MPa}$. 
Two-way ANOVA results revealed a significant difference among the tested groups $(\mathrm{p}<0.001)$.

The results of LSD test (Table 3 ) revealed that there was a significant difference in modulus of elasticity mean values among all archwires in control group. For tea, only St. St. mean value was significantly different from those of NiTi, $\mathrm{CuNiTi}$ and Teflon-coated NiTi archwires. For Coca Cola, there was a significant difference in modulus of elasticity mean values of St. St. and
Teflon- coated and those of NiTi and CuNiTi archwires.

Relative to NiTi archwire group, there was a significant difference in modulus of elasticity mean values between control and all other solutions, tea and other solutions and between Coca Cola and other solutions. For $\mathrm{CuNiTi}$ archwire group, there was a significant difference in modulus of elasticity mean values between control and all other solutions $(\mathrm{p}<0.001)$.

Table 3: Means and standard deviations (MPa) of modulus of elasticity of all tested groups.

\begin{tabular}{|c|c|c|c|c|c|c|}
\hline & $\begin{array}{c}\text { NiTi } \\
(\text { Mean+SD) }\end{array}$ & $\begin{array}{c}\text { CuNiTi } \\
(\text { Mean+SD) }\end{array}$ & $\begin{array}{c}\text { St. St. } \\
(\text { Mean+SD) }\end{array}$ & $\begin{array}{c}\text { Teflon-coated } \\
\text { NiTi } \\
(\text { Mean+SD) }\end{array}$ & P-value & $\begin{array}{c}\text { LSD } \\
\text { value }\end{array}$ \\
\hline $\begin{array}{c}\text { Artificial saliva } \\
\text { (control) }\end{array}$ & $5.79 \pm 0.01^{\mathrm{Aa}}$ & $7.33 \pm 0.12^{\mathrm{Ba}}$ & $14.81 \pm 0.21^{\mathrm{Ca}}$ & $6.46 \pm 0.41^{\mathrm{Da}}$ & $<0.0001$ & 0.4491 \\
\hline Tea & $5.29 \pm 0.14^{\mathrm{Ac}}$ & $5.25 \pm 0.15^{\mathrm{Ab}}$ & $12.95 \pm 0.31^{\mathrm{Bc}}$ & $5.05 \pm 0.19^{\mathrm{Ab}}$ & $<0.0001$ & 0.3917 \\
\hline Coca Cola & $5.07 \pm 0.18^{\mathrm{Ad}}$ & $5.47 \pm 0.04^{\mathrm{Ab}}$ & $12.29 \pm 0.49^{\mathrm{Bd}}$ & $6.23 \pm 0.24^{\mathrm{Ca}}$ & $<0.0001$ & 0.5454 \\
\hline P-value & $<0.0001$ & $<0.0001$ & $<0.0001$ & $<0.0001$ & & \\
\cline { 1 - 4 } LSD value & 0.2019 & 0.2509 & 0.5862 & 0.4643 & &
\end{tabular}

Means with the same superscript capital letters in the same raw and the same superscript small letters in the same column are not significantly different.

Regarding to St. St. archwire group, Coca Cola mean values were significantly different from those of the other solutions.For Teflon-coated NiTi archwire group, there was a significant difference in modulus of elasticity means of control and Coca Cola and those of tea solutions $(\mathrm{p}<0.001)$.

\section{Flexural strength}

Mean flexural strength values and standard deviations (MPa) of used orthodontic archwires in different solution specimens are shown in Table 4. The highest mean value was found to be $1.22+0.03 \mathrm{MPa}$ for St. St. in the control group. Two-way ANOVA results revealed a significant difference among the tested groups $(p<0.001)$.
The results of LSD test (Table 4) showed that there was no significant difference in flexural strength mean values between $\mathrm{NiTi}$ and $\mathrm{CuNiTi}$ archwires in all solutions except for Coca Cola. Moreover, there was a significant difference in flexural strength means between NiTi, St. St. and Teflon-coated NiTi archwires in all solution subgroups $(\mathrm{p}<0.001)$.

For NiTi, St. St. and Teflon-coated NiTi archwires, there was no significant difference in flexural strength mean values among all solution subgroups. For CuNiTi archwire, there was no significant difference in flexural strength mean values among all solution subgroups. 
Table 4: Means and standard deviations (MPa) of flexural strength of all tested groups.

\begin{tabular}{|c|c|c|c|c|c|c|}
\hline & $\begin{array}{c}\text { NiTi } \\
(\text { Mean+SD })\end{array}$ & $\begin{array}{c}\text { CuNiTi } \\
(\text { Mean+SD) }\end{array}$ & $\begin{array}{c}\text { St. } \mathbf{S t} . \\
(\text { Mean+SD) }\end{array}$ & $\begin{array}{c}\text { Teflon-coated } \\
\text { NiTi } \\
\text { (Mean+SD) }\end{array}$ & P-value & LSD value \\
\hline $\begin{array}{l}\text { Artificial saliva } \\
\text { (Control) }\end{array}$ & $0.45+0.04 \mathrm{Aa}$ & $0.37 \pm 0.07 \mathrm{Aa}$ & $1.22+0.03 \mathrm{Ba}$ & $0.53 \pm 0.03 \mathrm{Ca}$ & $<0.0001$ & 0.1007 \\
\hline Tea & $0.44+0.05 \mathrm{Aa}$ & $0.34+0.04 \mathrm{Aab}$ & $1.15+0.19 \mathrm{Ba}$ & $0.44+0.03 \mathrm{Ca}$ & 0.0003 & 0.2339 \\
\hline Coca Cola & $0.44 \pm 0.04 \mathrm{Aa}$ & $0.34 \pm 0.05 \mathrm{Bab}$ & $1.08+0.04 \mathrm{Ca}$ & $0.52+0.02 \mathrm{Da}$ & $<0.0001$ & 0.0876 \\
\hline P-value & 0.4801 & 0.1838 & 0.5515 & $<0.0001$ & & \\
\hline LSD value & 0.0753 & 0.0908 & 0.3444 & 0.0623 & & \\
\hline
\end{tabular}

Means with the same superscript capital letters in the same raw and the same superscript small letters in the same column are not significantly different.

\section{Discussion}

Orthodontic archwire is an essential part of any orthodontic appliance system. Alloys as stainless steel, cobalt chromium and titaniumcontaining alloys like nickel titanium, copper nickel titanium and titanium molybdenium alloys are commonly used in orthodontic treatment. ${ }^{14}$

The need for esthetic orthodontic devices is growing and the development of materials that show acceptable esthetics for the patients and an adequate clinical performance for orthodontists is required. ${ }^{15-20}$ This problem was partially solved by the application of esthetic ceramic or composite brackets. ${ }^{21-23}$ An esthetic archwire is highly desirable to complement esthetic brackets in clinical orthodontics. Metallic archwires coated with tooth colored resin materials, as synthetic fluorine-containing resin or epoxy resin are currently the present solution to this esthetic problem. ${ }^{23-27}$ Some authors ${ }^{28-3} 1$ have experienced problems with these coated archwires, assuming that the color tends to change with time and that the coating cracks during use in the oral cavity revealing the underlying metal.
Saliva, water and food in the oral cavity can dilute the acidic concentration keeping the $\mathrm{pH}$ above this critical level at which corrosion happens. ${ }^{25-30}$ Generally, although the same types of alloys were used in similar studies, the results differed. This may be because of the differences in the technology of materials manufacturing, galvanic coatings as well as differences in the structure of alloys and in the analytical techniques such as different sensitivities, detection limits and interferences. ${ }^{27-30}$ Although care was taken to simulate the conditions that present in the mouth as possible, regular washing action of saliva, sudden changes in temperature and $\mathrm{pH}$ could not be replicated..$^{51}$

The surface microhardness of the archwire affects the degree of wear ${ }^{21-25}$ as well as the frictional properties between the bracket and the archwire. ${ }^{23-28}$ This has a major importance in clinical orthodontics allowing sliding mechanics to occur as tooth tipping and uprighting. ${ }^{15-25}$ Vickers hardness test is used in this study as it is a microhardness test for measuring hardness of a small sized samples. The Vickers 
test can be used for all metals and has one of the widest scales among hardness tests. ${ }^{25}$

In the current study, St. St. archwire showed the hardest surface followed by NiTi, CuNiTi and Teflon-coated NiTi archwires in the control subgroup. Higher hardness values of stainless steel archwires could be attributed to clustering of carbon atoms and precipitation of carbides. ${ }^{17-19}$ This order is harmonious with the experimental results of other studies, ${ }^{19}$ who reported that St. St. archwire had the hardest surface followed NiTi, CuNiTi and TMA archwires. Other investigations $\mathrm{s}^{20-22}$ compared hardness of various archwires and found that St. St. was the hardest followed by cobalt chromium, TMA and Burstone et al., ${ }^{22}$ reported that the Vickers hardness of as received Copper Ni-Ti was $367 \mathrm{~kg} / \mathrm{mm} 2$ which was approximately similar to our result. This order was inconsistent with the results of $\mathrm{Li} \mathrm{Y}$ et al., ${ }^{17}$ who investigated the effect of decontamination and clinical exposure on the elastic modulus and hardness of NiTi and stainless steel archwires. This might be due to the different products used for each archwire type in the two studies. The variations in thermo-mechanical treatment among the products that may explain the different hardness values of archwires sharing the same elemental compositions.

After immersion in different testing solutions for 28 days, there was no significant difference in the surface microhardness of NiTi archwires in all solutions subgroups. This may be related to repassivation of the surface oxide layer in air and under wet conditions. ${ }^{18-21}$ This is in agreement with a study by other studies.,30 who examined the effect of soft beverages (orange juice, Coca Cola and energy drink Gatorade) on physical and chemical properties of NiTi orthodontic archwires. The archwires were immersed in $\quad 10 \mathrm{ml}$ of the beverage for $60 \mathrm{~min}$. No statistically significant differences in hardness, surface color change, topography or chemical structure were detected. The authors stated that the consumption of soft drinks did not cause the degradation of NiTi archwires.

In the current study, there was a significant effect in the surface microhardness of CuNiTi, St. St. and Teflon-coated NiTi archwires after immersion in the rest of testing solutions subgroups. These findings may be resulted from metal ions release from these archwires that adversely affect their mechanical and surface properties. Compared to $\mathrm{NiTi}$, the CuNiTi archwires were much more likely to show susceptibility to corrosion. Localized instability of the passive layer of CuNiTi archwire was reported as the copper has been added to the alloy on the expense of titanium and nickel. ${ }^{29-30}$ These results are in agreement with other studies. ${ }^{30-31}$ These studies reported significant differences in surface characteristics between control and other tested groups of the different metal archwires and brackets in different electrolyte solutions.

Modulus of elasticity (rigidity) is another variable that influences the success of any given treatment phase. Clinically, it represents the magnitude of the force required to deflect or bend an archwire. In an attempt to improve the biological environment for tooth movement and minimize the patient's discomfort, the initiation of treatment requires low stiffness archwires capable of producing lighter and constant forces during archwire deactivation..$^{28-30}$

The results of the current study showed that there was a significant difference in modulus of elasticity of all tested groups in the solutions specimens with high mean values for St. St. archwires. This is in agreement with the finding of previous studies ${ }^{23-29}$ which evaluated the 
effect of topical fluoride treatment on mechanical properties and surface characterization of beta titanium and stainless steel orthodontic archwires.

Biodegradation from titanium based orthodontic archwires in testing solutions have been illustrated as a causative factor in corrosion of NiTi based alloys. This is due to diffusion of hydrogen through interstitial sites, dislocations and grain boundaries reacting with lattice atoms to form titanium hydride. Titanium hydrides have been reported to form a body-centered tetragonal structure which is considered to be the cause of deterioration of the mechanical properties of the alloy. ${ }^{15-20}$ Trapped interstitial hydrogen molecules might be associated with the decrease in the elastic modulus of stainless steel archwire after exposure to the testing solutions. ${ }^{19-25}$ Contrasting the results of the present study, other studies ${ }^{10,30}$ concluded that soft drinks had no significant effect on the modulus of elasticity of nitinol heat activated archwires. The differences in values for the same mechanical properties of each archwire type are attributed to the different products evaluated, variations in $\mathrm{pH}$, concentrations of testing solutions and the different temperatures during the three point bending tests (room temperature in this study).

Regarding flexural strength, the maximum bending moment of an orthodontic archwire is an essential parameter in the design and application of an orthodontic device. It is the archwire feature that decides how much force an appliance can deliver. ${ }^{6-10}$

The results indicate a superior flexural strength for St. St. followed by Teflon-coated $\mathrm{NiTi}$, NiTi and CuNiTi archwires respectively in control subgroups. These findings agree with a previous study ${ }^{17}$ who found that the maximum bending moment is largest in stainless steel, beta titanium and nickel titanium for the same cross section.
The results of the current study showed that there was no significant difference in the flexural strength of all tested archwires in the solution specimens. The reason why only the modulus of elasticity would be affected might be related to absorbed hydrogen molecules not causing any evident effect within the lattice until the archwire has been loaded beyond the elastic range, when lattice dislocations and slip occur. 15 The hydrogen penetration in the lattice of orthodontic alloys could interfere with the lattice's ability to undergo the unloading phase shift from the martensitic form to the austenitic form. ${ }^{6}$ Contrasting the findings of the present study, a recent research ${ }^{28}$ stated that immersion of NiTi archwires in the fluoridated and acidic medium showed a statistically significant reduction of their mechanical properties.

Despite the importance of the findings in this study, further in vivo studies should be conducted for more clarification and confirmation of the results.

\section{Conclusions}

Based on the results and within the limitations of this study, it could be concluded that different beverages could potentially contribute to biodegradation of orthodontic archwires leading to prolonged orthodontic treatment and might decrease the mechanical properties of orthodontic archwires.

\section{Reference}

1. Eliades T. Orthodontic materials research and applications: part 2. Current status and projected future developments in materials and biocompatibility. American Journal of Orthodontics and Dentofacial Orthopedics. 2007;131(2):253-62.

2. Krishnan V, Kumar KJ. Mechanical properties and surface characteristics of three archwire alloys. The Angle Orthodontist. 
2004;74(6):825-31.

3. Wichelhaus A, Geserick M, Hibst R, Sander FG. The effect of surface treatment and clinical use on friction in NiTi orthodontic wires. Dental Materials. 2005;21(10):938-45.

4. Kusy RP, Whitley JQ, Mayhew MJ, Buckthal JE. Surface roughness of orthodontic archwires via laser spectroscopy. The Angle Orthodontist. 1988;58(1):33-45.

5. Widu F, Drescher D, Junker R, Bourauel C. Corrosion and biocompatibility of orthodontic wires. Journal of Materials Science: Materials in Medicine. 1999;10(5):275-81.

6. Downing A, McCabe J, Gordon P. A study of frictional forces between orthodontic brackets and archwires. British Journal of Orthodontics. 1994;21(4):41-6.

7. Tselepis M, Brockhurst P, West VC.

The dynamnic frictional resistance between orthodontic brackets and arch wires. American Journal of Orthodontics and Dentofacial Orthopedics. 1994;106(2):131-8.

8. Taylor NG, Ison K. Frictional resistance between orthodontic brackets and archwires in the buccal segments. The Angle Orthodontist. 1996;66(3):215-22.

9. Hunt N, Cunningham S, Golden C, Sheriff M. An investigation into the effects of polishing on surface hardness and corrosion of orthodontic archwires. The Angle orthodontist. 1999;69(5):433-40.

10. Rapiejko C, Fouvry S, Grosgogeat B, Wendler B. A representative ex-situ fretting wear investigation of orthodontic arch-wire/bracket contacts. Wear. 2009;266(7):850-8.
11. Obi-Egbedi N, Obot I, Umoren S. Spondias mombin L. as a green corrosion inhibitor for aluminium in sulphuric acid: correlation between inhibitive effect and electronic properties of extracts major constituents using density functional theory. Arabian Journal of Chemistry. 2012;5(3):361-73.

12. Specifications GP. Surface Texture: Profile Method-Terms, Definitions and Surface Texture Parameters. International Organisation for Standardisation, Geneva. 1997.

13. Matarese G, Nucera R, Militi A, Mazza M, Portelli M, Festa F, et al. Evaluation of frictional forces during dental alignment: an experimental model with 3 nonleveled brackets. American Journal of Orthodontics and Dentofacial Orthopedics. 2008;133(5):708-15.

14. Kusy RP, Whitley JQ, editors. Friction between different wire-bracketconfigurations and materials. Seminars in orthodontics; 1997: Elsevier.

15. Oguzie EE. Evaluation of the inhibitive effect of some plant extracts on the acid corrosion of mild steel. Corrosion science. 2008;50(11):2993-8.

16. Ashassi-Sorkhabi H, Shaabani B, Seifzadeh D. Effect of some pyrimidinic Shciff bases on the corrosion of mild steel in hydrochloric acid solution. Electrochimica Acta. 2005;50(16):3446-52.

17. Li Y, Guo C, Yang J, Wei J, Xu J, Cheng S. Evaluation of antioxidant properties of pomegranate peel extract in comparison with pomegranate pulp extract. Food chemistry. 2006;96(2):254-60.

18. Poyrazoğlu E, Gökmen V, Artık N. 
Organic acids and phenolic compounds in pomegranates (Punica granatum L.) grown in Turkey. Journal of food composition and analysis. 2002;15(5):567-75.

19. Ferreira E, Giacomelli C, Giacomelli F, Spinelli A. Evaluation of the inhibitor effect of L-ascorbic acid on the corrosion of mild steel. Materials Chemistry and Physics. 2004;83(1):129-34.

20. Oguzie EE. Corrosion inhibitive effect and adsorption behaviour of Hibiscus sabdariffa extract on mild steel in acidic media. Portugaliae Electrochimica Acta. 2008;26(3):303-14.

21. Yu J-H, Wu L-C, Hsu J-T, Chang Y-Y, Huang H-H, Huang H-L. Surface roughness and topography of four commonly used types of orthodontic archwire. J Med Biol Eng. 2011;31(5):164:1-16.

22. Burstone CJ, Goldberg AJ. Beta titanium: a new orthodontic alloy. American journal of orthodontics. 1980;77(2):121-32.

23. Cacciafesta V, Sfondrini MF, Ricciardi A, Scribante A, Klersy C, Auricchio F. Evaluation of friction of stainless steel and esthetic self-ligating brackets in various bracketarchwire combinations. American Journal of Orthodontics and Dentofacial Orthopedics. 2003;124(4):395-402.

24. Kapila S, Sachdeva R. Mechanical properties and clinical applications of orthodontic wires. American Journal of Orthodontics and Dentofacial Orthopedics. 1989;96(2):100-9.

25. Mendes K, Rossouw PE, editors. Friction: validation of manufacturer's claim. Seminars in
Orthodontics; 2003: Elsevier.

26. Kusy R, Whitley J, Q. Coefficients of friction for arch wires in stainless steel and polycrystalline alumina bracket slots. I. The dry state. American Journal of Orthodontics and Dentofacial Orthopedics. 1990;98(4):300-12.

27. Marques ISV, Araújo AM, Gurgel JA, Normando D. Debris, roughness and friction of stainless steel archwires following clinical use. Angle Orthodontist. 2010;80(3):521-7.

28. Yu J-H, Wu L-C, Hsu J-T, Chang Y-Y, Huang H-H, Huang H-L. Surface roughness and topography of four commonly used types of orthodontic archwire. J Med Biol Eng.

2011;31(5):367-70.

29. Abalos C, Paúl A, Mendoza A, Solano E, Gil F. Influence of topographical features on the fluoride corrosion of Ni-Ti orthodontic archwires. Journal of Materials Science: Materials in Medicine. 2011;22(12):2813-21.

30. Incerti Parenti S, Guicciardi S, Melandri C, Sprio S, Lafratta E, Tampieri A, et al. Effect of soft drinks on the physical and chemical features of nickel-titanium-based orthodontic wires. Acta Odontologica Scandinavica. 2012;70(1):49-55. 31. Kwon YH, Jang C-M, Jang J-H, Park J-H, Kim T-H, Kim H-I. Effect of fluoride released from fluoride-containing dental restoratives on NiTi orthodontic wires. Dental materials journal. 2008;27(1):133-8. 

